\title{
THE IMPACT OF THE DELETION OF SECTION 11 (BA) ON THE DEDUCTIBILITY OF PRE-PRODUCTION RAISING FEES INCURRED IN THE EXPANSION OF AN EXISTING TRADE
}

\author{
Gerhard Barkhuizen* \\ Stellenbosch University \\ Gerhard.barkhuizen@gmail.com
}

Received: November 2014

\author{
Leonard Willemse* \\ Stellenbosch University \\ Leonard.willemse@mazars.co.za
}

Accepted: July 2015

\begin{abstract}
Section 11(bA) was recently deleted and replaced by section 11A in the Income Tax Act No. 58 of 1962 ("the Act" - all references to sections and paragraphs hereafter refer to the Act, unless otherwise indicated). Section $1 \mathrm{l}(\mathrm{bA})$ and section $11 \mathrm{~A}$ determined the income tax treatment of qualifying preproduction interest incurred. The article focused on whether or not pre-production raising fees incurred by the taxpayer during the expanding of an existing trade will be deductible in terms of section $11(\mathrm{bA})$ or section 11A. Section $11(\mathrm{bA})$ and section 24J allow for the deduction, in certain circumstances, of interest or related finance charges. In the recently decided C:SARS v South African Custodial Services (Pty) Ltd 2012 (1) SA 522 (SCA), 74 SATC 61 ("SA Custodial") it was found by the court that raising fees can be read under the phrase interest or related finance charges in terms of section $11(\mathrm{bA})$. The question arose whether or not the taxpayers are being disadvantaged by the fiscus through the deletion of section $11(\mathrm{bA})$ and its replacement by section $11 \mathrm{~A}$, especially in regard to pre-production raising fees incurred during the expansion of an existing trade. This article investigates the interaction between sections $1 \mathrm{l}(\mathrm{bA}), 1 \mathrm{AA}$ and 24J of the Act in order to determine the difference in the income tax treatment between these sections for the pre-production raising fees incurred. The result of the investigation into the interaction of these sections will indicate whether or not the taxpayer is being disadvantaged by the fiscus through the deletion of section $11(\mathrm{bA})$ and its replacement by section $11 \mathrm{~A}$.
\end{abstract}

Keywords

Income Tax Act No. 58 of 1962 (as amended), raising fees, interest or other related fees, pre-production deductions, trade, brought into use.

*Mr G Barkhuizen is a past master's student in the School of Accounting, Stellenbosch University, South Africa.

\#Mr L Willemse is a lecturer in the School of Accounting, Stellenbosch University, South Africa. 


\section{INTRODUCTION AND BACKGROUND}

Loans are subject to a variety of terms and conditions and in most instances additional fees over and above the interest charge which are levied by the financial institution from whom the taxpayer obtained the finance funding. These additional fees include holding fees for providing of credit facilities, investigation fees, guarantee fees and arrangement fees. Collectively these fees are known as raising fees. Zulman, Stretch and Silke (2013, [s.a.]) indicate that raising fees can take the form of a percentage of a loan or a fixed amount. Raising fees are not defined in the Act (Stretch \& Silke, 2000, [s.a.]) and no section in the Act directly refers to raising fees. It therefore follows that the interpretation given to the term by the South African courts should be followed and if there is no such case law, the literal meaning of the words need to be analysed to determine the income tax treatment thereof.

Recently the South African Supreme Court of Appeal ("Appeal Court") held that raising fees incurred by the taxpayer falls within the definition of interest or related finance charge as found in the now-deleted section $11(\mathrm{bA})$. Interest (including related finance charges) which qualified to be deducted in terms of section $1 \mathrm{l}(\mathrm{bA})$ could be deducted immediately when the asset was brought into use in the taxpayer's trade. Stiglingh, Koekemoer, van Schalkwyk, Wilcocks, de Swardt and Jordaan (2011:267) refer to these type of interest as pre-production interest. This section was deleted with effect from 1 January 2012 and effectively replaced with section 11A. Section 11A, however, allows for a deduction of expenditure and losses only in as far as it would have been allowed under sections 11 and 24J. The result thereof is that the deduction allowable in terms of section I1A is the amount which would have been allowed under section 24J had a trade already commenced. The section $11 \mathrm{~A}$ deduction may be deducted only once the carrying out of a trade has commenced (Interpretation Note No. 51, 2009:6).

The change in sections has left the taxpayers in an unenviable position in that uncertainty has been created regarding whether or not pre-production raising fees incurred specifically to expand an existing are deductible or not for income tax purposes.

\section{PROBLEM STATEMENT}

The recently deleted section $11(\mathrm{bA})$ allowed the full amount of related finance charge to be deducted for income tax purposes, as long as it was with regard to a qualifying asset. Due to the deletion of section $11(\mathrm{bA})$, which used to govern the income tax treatment of pre-productionrelated finance charges, a case can be made that the expenditure should now be deducted under section IlA if all the relevant requirements are made under section 24J. This is due to section 24J determining the section 11 A deduction. Such a deduction, however, will be spread over the term of the loan if all the relevant requirements of section 24J are met and only the cumulative portion since incurring of the related finance charge to the commencement of the carrying out of a trade will be allowable under section 11A. There is thus a timing difference between the deduction of related finance charges in terms of section $11(\mathrm{bA})$ and sections $11 \mathrm{~A}$ and 24J.

The aim of this article is to investigate whether or not the taxpayer is being disadvantaged by the fiscus due to the deletion of section $11(\mathrm{bA})$ and its replacement by section 11A (and the subsequent deduction based on the workings of section 24J). This article explores the abovementioned specifically relating to pre-production-related finance charges incurred to expand an existing trade. 


\section{OBJECTIVES AND RESEARCH METHODOLOGY}

The article's main objective is to understand whether the taxpayer who incurred pre-productionrelated finance charge is being disadvantaged by the fiscus through the deletion of section $11(b A)$ and its replacement by section 11A. The article will focus mainly on the income tax treatment of taxpayers who incurred pre-production-related finance charges to expand an existing trade. The article will focus on historical information to achieve the aim of the article, which will include:

- Relevant South African legislation;

- Relevant South African court rulings; and

- The views of recognised income tax experts, as contained in textbooks and journals.

To achieve these objectives, the article will address the following secondary problem statements:

- Whether or not reasonable grounds exist to support the premise that raising fees can be seen as related finance charged and the deductibility thereof in terms of section 11 (bA) and section 24J;

- The interaction between section $11 \mathrm{~A}$, section 11 (bA) and section 24);

- Whether or not pre-production raising fees (which were incurred to expand an existing trade) are deductible for income tax purposes in terms of section 11 A or section 24).

\section{CAN RAISING FEES BE SEEN AS INTEREST OR RELATED FINANCE CHARGES?}

As discussed earlier, raising fees include a variety of fees which are mostly incurred when loan financing is obtained. De Koker and Williams (2014, [s.a.]) in Silke on South African Income Tax at paragraph 8.90 are of the opinion that raising fees can be seen as related finance charges. The term related finance charges was also previously present in the Act in section 11(bA) prior to the deletion of the section. The term related finance charge is also part of section $24 \mathrm{~J}(\mathrm{l})$, where this is specifically included in the definition of interest, as it is in section $11(\mathrm{bA})$. Section 24J spreads the qualifying section 24J interest income tax deduction over the period of the loan.

Interest is defined in Black's Law Dictionary (2008:829) as "The compensation fixed by agreement or allowed by law for the use or detention of money, or for the loss of money by the one who is entitled to its use, especially the amount owed to a lender in return for the uses of borrowed money - Also termed finance charge". The dictionary meaning of interest and finance charges can therefore be seen as the same items. The interest definition as found in section 24J reads follows:

"Interest includes the -

(a) gross amount of any interest or related finance charges, discount or premium payable or receivable in terms of or in respect of a financial arrangement" 
The intention of the legislature regarding the items which could possible fall within the meaning of the word interest at the time when section 24J was promulgated into the Act can be found in the Explanatory Memorandum on the Income Tax Bill (1995:11), which stated the following:

"'Interest' - the definition is not exhaustive and includes the gross amount of any interest or related finance charges, discount or premium payable or receivable in terms of a financial arrangement."

It is submitted that the meaning of interest provided by the legislature, as found in the explanatory memorandum, includes a wide variety of expenditure and losses which are similar to that of interest, which includes related finance charges. Stretch and Silke (2000, [s.a.]) are however of the opinion that a distinction can be made between interest and raising fees in that raising fees are the cost of obtaining capital, while interest is the cost of the usage of the capital.

Income tax experts hold different views regarding the income tax treatment of raising fees. Williams (1997:114) and Brincker (201la, [s.a.]) are of the view that raising fees are in certain circumstances capital of nature and not deductible for income tax purposes. Williams (1997:114) goes further and states that interest and raising fees are qualitatively different to one another. In contrast to these views is the view held by De Jager (1987:11), who holds the view that raising fees are the same as interest and that the income tax treatment of these two items must agree with each other. De Jager states that both interest and raising fees are part of the cost of borrowing money. The fact that raising fees are directly related to the amount and term of the loan is also indicated to be seen as additional evidence that the income tax treatment of interest and raising fees should agree. De Villiers (2001:42) holds the opinion that the term related finance charges includes raising fees in the term interest or related finance charges.

The South African courts hold divergent views on the issue. The appeal court held in CIR v Genn \& Co (Proprietary) Limited 1955 (3) SA 293 (A), 20 SATC 113 ( "Genn \& Co") that raising fees are deductible due to the fact that a distinction cannot be made between raising fees and interest (Brincker, 201la, [s.a.]). Schreiner JA made the following remarks in this case on page 119:

"It should I think be observed at the outset that, whatever might be the position on other facts, it is not possible in the present case to justify a difference in treatment between the interest on the loans and the commissions; the circumstances mentioned above show that in each case the commission together with the interest formed in effect one consideration which the company had to pay for the use of the money for the period of the loan. Although, therefore, the commissioner allowed the deduction of the interest, as distinguished from the commission, the principles to be followed are on the present facts equally applicable to both."

The income tax courts in ITC 882 (1959) 23 SATC 239 (T) made the ruling that a distinction can be made to the Genn \& Co case in that in the particular circumstances the loans were received by the taxpayer to ensure that capital assets were purchased and not inventory. Raising fees was also found not to be deductible in ITC 995 (1962) 25 SATC 137 (T) and ITC 1019 (1962) 25 SATC 411 (N) as different grounds to those of Genn \& Co were found by the court. It can therefore be summarised that the South African income tax courts made their rulings based on the fact that the purpose of the loans should be considered in determining the income tax treatment of raising fees.

The South African Appeal Court however recently held in favour in allowing the deductibility of raising fees in the SA Custodial case. The taxpayer was tasked with the building of prison facilities in the Louis Trichardt district and needed to obtain financing as per the terms of the 
contract. Several fees were required to be paid by the taxpayer to be able to obtain the required loan funding from the financial institutions, including guarantee fees, introduction fees, financial advisory fees, margin fees, commitment fees, initial fees, administration fees as well as legal fees. Brincker (201lb, [s.a.]) referred to these fees as raising fees; however, he questioned the fact that the court ruled legal fees to be of the same nature as financial advice fees. The taxpayer argued that for him to obtain the necessary funding to fulfil the terms and conditions of the contract, he needed to incur raising fees. The taxpayer was of the opinion that such raising fees could be deducted under section $11(\mathrm{bA})$ in terms of it being a related finance charge. The section reads as follows:

"any interest (including related finance charges) which is not otherwise allowable as a deduction under this Act, which has been actually incurred by the taxpayer on any loan, advance or credit utilized by him for the acquisition, installation, erection or construction of any machinery, plant, building, or any improvements to a building, or any pipeline, transmission line or cable or railway line as contemplated in section 12D, or any aircraft hangar, apron, runway or taxiway as contemplated in section $12 \mathrm{~F}$, to be used by him for the purposes of his trade, and which has been so incurred in respect of a period prior to such machinery, plant, building, improvements, pipeline, transmission line or cable, railway line, aircraft hangar, apron, runway or taxiway, being brought into use for the purposes of the taxpayer's trade, such deduction to be allowed in the year of assessment during which such machinery, plant, building, improvements, pipeline, transmission line or cable, railway line, aircraft hangar, apron, runway or taxiway is or are brought into use for the said purposes;"

Plasket $\int$ found that the interest incurred by the taxpayer was deductible in terms of section $11(b A)$ due to it being incurred by the taxpayer in relation to the loan obtained for the building of the prison. The raising fees were also deducted in terms of section $11(\mathrm{bA})$ due to the close relationship in the obtaining of the loans and them being classified as related finance charge.

It was therefore found by the Court that raising fees incurred on a loan of a capital nature are deductible in terms of section 11 (bA). Brincker (2011b, [s.a.]) criticised the ruling based on the principles that were laid down by the income tax courts and not considered by the Appeal Court, namely whether or not the loan is fixed capital or floating capital in the hands of the taxpayer.

The Appeal Court created legal precedent in creating a direct relationship between finance charges and interest in the SA Custodial case in ruling that raising fees are closely related to the obtaining of loans where interest will be incurred. It is submitted that the interpretation of law principle, stare decisis, entails that legal precedent is created by the Appeal Court's ruling and that all lower courts are bound by the decisions of a higher court or that of a full bench on the same court level. The South African courts, with the exception of the Constitutional Court, are therefore bound by the SA Custodial decision. It can therefore be submitted that unless grounds can be found to differentiate the particular case from the SA Custodial case, raising fees will be deductible for income tax in terms of section $11(\mathrm{bA})$. Schultz JA summarised this interpretation of law in Robin Consolidated Industries Ltd v CIR 1997 (3) SA 654 (SCA), 2 All SA 195 (A) ("Robin Consolidated"):

"However, I should state again, that for good reason this court is reluctant to depart from its own decisions ... and that once the meaning of the words of a section in an Act of Parliament have been authoritatively determined by this court, that meaning must be given to them, even by this court, unless it is clear to it that it has erred ... Particularly it is important to observe stare decisis when a decision has been acted on for a number of years in such a manner that 
rights have grown up under it ... For 45 years businessmen and the revenue have been ordering their affairs on the assumption that the SA Bazaars case laid down the law."

There has been no material change in the context in which the rule in that case operates, so that this would have been a case in which this court would have been especially slow to depart from its earlier decision."

It is important to note for this article that section $11(\mathrm{bA})$ has however been deleted from the Act. The only other section that refers to interest or related finance charge is section 24J. This question can be asked whether or not the same meaning as given to interest or related finance charge by the Appeal Court in SA Custodia/can be given in context of section 24J.

Interpretation of law principles indicate that if a certain meaning is given to a certain set of words, the same meaning should also be given to the same set of words in other sections in the Act. Kellaway (1995:74) states that if the legislature uses the same wording in the same act, that these words must carry the same meaning. Steyn JA confirmed this in his ruling in Minister of the Interior v Machadodorp Investments (Pty) Ltd 1957 (2) SA 395 (A), 2 All SA 355 (A) on page 404 where he made the following comments:

"... it may reasonably be supposed that out of a proper concern for the intelligibility of its language, it would intend the word to be understood, where no clear indication to the contrary is given, in the same sense throughout the enactment."

It is submitted that the same meaning as given to interest or related finance charges as per section 11(bA) should be given in section 24J. Kellaway (1995:74) also confirms this interpretation of law by indicating that South African courts should give the same wording found in a different section of the act the same meaning.

\section{INTERACTION BETWEEN SECTION 11(BA), SECTION IIA AND SECTION 24J}

The Act currently governs the income tax deduction of interest or related finance charges in section 24J and indirectly through the workings of section 11A. Previously the Act included section $11(\mathrm{bA})$, which contained income tax deduction for the term interest or related finance charges. The main difference between section $11(\mathrm{bA})$ and section $11 \mathrm{~A}$ is that section $11 \mathrm{~A}$ is limited to expenditure incurred prior to the commencement of trade, while section 11 (bA) refers to interest or related finance charges incurred prior to the asset being brought into use in carrying out of the trade of the taxpayer. It is held that in terms of current legislation (section $11 A$ ) the income tax treatment of pre-production-related finance charges will be determined based on when the carrying on of a trade commences.

Determining when the carrying on of a trade begins is a question of fact which will be determined by the courts from case to case. Guidelines have been laid down by the South African courts in previous court cases which will assist the taxpayer in determining when the carrying on of a trade commences. The issue regarding whether a trade is carried on during the expansion of an existing business is a matter in which uncertainty currently remains.

Clegg (2012, [s.a.]) also indicates his concern that the Commissioner for the South African Revenue Service has taken no clear stance regarding when a trade is carried out. In Interpretation Note No. 51 the South African Revenue Service (2009:8) indicated that expenditure incurred in bringing an asset into use when an existing trade is being expanded is of a capital nature and that the expenditure is not incurred in terms of the existing trade. As a 
result it is submitted that when a taxpayer is expanding an existing trade through the creation of a capital asset to be used in this existing trade it will not be incurred in the existing trade. It can therefore be submitted that the expenditure should be deducted in terms of section $11 \mathrm{~A}$ and not section 24J.

The relevant parts of the section 11 A definition reads as follows:

"Section 11A. Deductions in respect of expenditure and losses incurred prior to commencement of trade.

(1) For purposes of determining the taxable income derived during any year of assessment by a person from carrying on any trade, there shall be allowed as a deduction from the income so derived, any expenditure and losses-

(a) actually incurred by that person prior to the commencement of and in preparation for carrying on that trade;

(b) which would have been allowed as a deduction in terms of section 11 (other than section $11(\mathrm{x})$ ), 11B, 11D or 24J had the expenditure or losses been incurred after that person commenced carrying on that trade; and

(c) which were not allowed as a deduction in that year or any previous year of assessment.

(2) So much of the expenditure and losses contemplated in subsection (1) as exceeds the income derived during the year of assessment from carrying on that trade after deduction of any amounts allowable in that year of assessment in terms of any other provision of this Act, shall not be set off against any income of that person which is derived otherwise than from carrying on that trade, notwithstanding section 20(1)(b)."

Interpretation Note No. 51 (2009:17) indicates that section 11(bA) takes precedence over section $11 \mathrm{~A}$, because section $11 \mathrm{~A}(\mathrm{l})(\mathrm{b})$ requires that the trade has commenced for the pretrade expenditure to be deductible in terms of section 11 . This condition has not yet been met, as section $11(\mathrm{bA})$ has an additional requirement that the asset must also have been brought into use. The uncertainty regarding whether section $11(\mathrm{bA})$ or section $11 \mathrm{~A}$ governs the income tax deductibility of pre-production interest has however been removed as a result of the deletion of section 11 (bA) from the Act.

A critical evaluation of section $11(\mathrm{bA})$ and section $11 \mathrm{~A}$ is required to understand whether or not the taxpayer has been disadvantaged by the fiscus through the deletion of section $11(b A)$ and its replacement by section 11A. The first difference, as already discussed, is the timing of the deductibility of the expenses and losses that are permitted to be deducted in terms of section $11(\mathrm{bA})$ and 11A. Section 11A applies to all interest or related finance charges, as far as this would have been admissible under section 24J, before the relevant trade commence. The section $11 \mathrm{~A}$-accrued deduction will be allowed as soon as the trade commences. Expenditure and losses incurred after the commencement of the trade will not be deductible in terms of section 11A. The interest or related finance charges incurred after the commencement of the carrying on of a trade will be deductible in terms of section 24J. Section $11(\mathrm{bA})$ however allows for the deduction of the qualifying pre-production interest and related finance charge incurred until the date the asset is brought into use, even though the trade has already commenced. The timing of the deduction of expenditure and losses will incur first in terms of section $11 \mathrm{~A}$ than that of section 
$11(b A)$ if the qualifying asset is brought into use after the commencement of the carrying on of a trade.

Section $11 \mathrm{~A}(2)$ contains a restriction on the amount allowed as deduction in the year in which the carrying on of that trade commence, despite the wording of section 20(1)(b). Section $20(1)$ (b) allows a taxpayer to use the assessed losses incurred in a trade to be offset with taxable income from a different trade. The specific wording of section $11 \mathrm{~A}(2)$ overrules the wording as per section $20(1)(b)$. Thus any assessed loss from the new trade will be ring-fenced within this trade and only income from this trade can be used against this ring-fenced assessed loss. If a taxpayer therefore has no taxable income from this trade but has taxable income from another trade, the section IIA deduction cannot be used against the other trade's taxable income, despite the wording of section $20(1)$ (b). Section 11A-deductible amounts may also not create or increase an assessed loss.

In contrast to section $11 \mathrm{~A}$, section $11(\mathrm{bA})$ contains no restriction that prevents an assessed loss from being created or enlarged. Furthermore, the section $11(\mathrm{bA})$ deduction can be deducted against any trade of the taxpayer. Section $11(b A)$ is limited only by the fact that the asset must be brought into use in the carrying on of a trade before it may be deducted.

A further difference between these two sections exists regarding the value of the amount that is allowed as a deduction when all the requirements of the two sections have been met. If the interest or related finance charge is deductible under section 11A, the Act clearly indicates that the amount deductible should agree to the amount which would have been allowed as a deduction under section 24J if the trade has already commenced. Section 24J spreads the deduction of the interest or related finance charges over the period of the instrument. In contrast, section $1 \mathrm{l}(\mathrm{bA})$ allows for a full deduction as soon the asset is brought into use in the carrying on of a trade. It is possible that a period exists between the commencement of the carrying on of a trade and the asset being brought into use which will be governed by section $11(\mathrm{bA})$ and not by section 11A. Section $11 \mathrm{~A}$ is not applicable in this period due to the deduction having to be taken as soon as the carrying on of the trade commences. The difference in the amount allowed as a deduction at different time intervals has raised the question whether or not the taxpayer has been disadvantaged by the fiscus due to the change in legislation.

Section 24J was initially introduced into the Act to determine the timing of the interest deduction and was not originally intended to be a charging section (Stiglingh et al., 2011:673). The Act was however amended in 2004 to change section 24J into a charging section for interest (Explanatory Memorandum on the Revenue Laws Amendment Bill, 2004:20). Section 11(a) determined the income tax deductibility of interest before this amendment to the Act. Section 24J's charging section as is currently found in section 24J(2) reads as follows:

(2) Where any person is the issuer in relation to an instrument during any year of assessment, such person shall for the purposes of this Act be deemed to have incurred an amount of interest during such year of assessment, which is equal to-

(a) the sum of all accrual amounts in relation to all accrual periods falling, whether in whole or in part, within such year of assessment in respect of such instrument; or

(b) an amount determined in accordance with an alternative method in relation to such year of assessment in respect of such instrument, 
which must be deducted from the income of that person derived from carrying on any trade, if that amount is incurred in the production of the income."

It is important to note that interest or related finance charges will be spread over the term of the instrument in terms of section 24J on a day-to-day basis (the Act refers to this as the "yield to maturity") or in terms of the alternative method (Stiglingh et al., 2011:675). The description of the alternative method in the Act prescribes that this method can be used only if the result thereof will not differ materially from the yield to maturity method. Due to the fact that both methods should produce more or less the same result, the article will focus only on the yield to maturity method. An important component of section 24J's yield to maturity calculation is that there must be an "accrual amount". The accrual amount is calculated by multiplying the adjusted initial amount by the yield to maturity (Stiglingh et al., 2011: 678).

Emslie (2010:4) indicates that for interest to be deducted in terms of section 24J(2) there must be both an instrument and an issuer. Raising fees are incurred in terms of an "instrument". It is submitted that due to the fact that the loan amount and the loan raising fees are known, it is possible to calculate the "yield to maturity" rate. An instrument is defined by the Act as any form of an interest-bearing arrangement, whether in writing or not. The Act defines issuer as follows:

"issuer", in relation to any instrument-

a) means any person who has incurred any interest or has any obligation to repay any amount in terms of such instrument; or

b) at any particular time, means any person who, if any interest payable in terms of such instrument was due and payable at that time, would be liable to pay such interest;

It is submitted that both an instrument (loan obtained) and issuer (the taxpayer who has incurred the raising fees when obtaining the loan) are applicable when raising fees are incurred by a taxpayer. These requirements of section $24 \mathrm{~J}$ are therefore met.

Section 24J allows for a deduction only if the expenditure or losses are incurred in the production of income and the carrying on of a trade has commenced (Witthoft, 2011, [s.a.]). Section $11 \mathrm{~A}$ allows for a deduction insofar as it would be admissible under section 24J. The date when the carrying on of a trade commences is crucial because it determines whether section 24J or section $11 \mathrm{~A}$ applies. Interest or related finance charges have to been incurred in the carrying on of a trade to be deductible in terms of section 24J. The section $11(\mathrm{bA})$ raising fees incurred before the commencing of the carrying on of a trade will be deductible in terms of section $11(b A)$ as soon as the asset is brought into use in the carrying on of the trade.

Unlike section $11(\mathrm{bA})$, section 24J does not contain a limitation that interest or related finance costs may not be of a capital nature. However, section $11(\mathrm{bA})$ contains a proviso that interest or related finance costs may not be of a capital nature. It seems, however, following the $S A$ Custodia/case that the proviso that expenditure and losses may not be of a capital nature is no longer relevant because of the legal principle of stare decisis and judicial precedent set by the Appeal Court.

Finally, section 24J spreads the deductible amount of interest or related finance charges over the term of the instrument, while section $11(\mathrm{bA})$ allows for the deduction in full when the asset is brought into use. There is a significant difference in the period over which raising fees may be 
deducted in terms of section 24J (spread over the term of the loan) and section 11(bA) (immediately when the asset is brought into use in the carrying on trade).

\section{INCOME TAX TREATMENT OF PRE-PRODUCTION RAISING FEES INCURRED IN EXPANDING AN EXISTING TRADE}

It has already been submitted that the interest or related finance charges may be deducted only when the taxpayer's trade has commenced as well as the asset having being brought into use (Brincker, 201la, [s.a.]). This is a very important difference from section 11A, where interest or related finance charge is deductible only when the taxpayer's trade commences. It is submitted that the expansion of an existing trade constitutes a new trade. Raising fees incurred in the expansion of an existing trade will as a result constitute pre-trade expenditure. Pre-production raising fees would have been deductible in terms of the interpretation of law, stare decisis, from the SA Custodia/case, had section 11 (bA) still been in force.

The pre-production raising fees deduction in terms of section $11(\mathrm{bA})$ would have been available in full for the taxpayer at the time of the asset being brought into use. The deduction will not be spread over the term of the loan or instrument as required by section 24J(2). The practical implementation thereof will be illustrated in the examples that follow.

It is submitted that the actual income tax consequences of the deletion of section $11(\mathrm{bA})$ and its replacement with section IlA can be determined only if like is compared with like. Correia, Flynn, Uliana and Wormald (2013:2-16) indicate that the present value of future cash flows can be seen as the value of the cash flows if received today. The principle also includes that a rand received today is worth more than a rand received in the future due to the fact that a rand received now can be immediately used productively to ensure more value in the future (Correia et al., 2013:2-16). Different investments with different future cash flows may be compared with one another if the present value of each is calculated (Correia et al., 2013:2-15).

The actual income tax deductions in terms of sections $11(\mathrm{bA}), 11 \mathrm{~A}$ and $24 \mathrm{~J}$ will accrue in various periods. The present value of the cash flows of the various sections will be calculated to determine the most advantageous section. The discount rate used in this article to determine the net present value ("NPV") of the deductions is $5.4 \%$. This percentage agrees with the Consumer Price Index rate for December 2013 (Consumer Price Index, 2013:2014, [s.a.]).

The value of the raising fees that are deductible (accrual amount) is calculated in terms of section 24J. This article will focus only on the yield to maturity method as prescribed in section 24J.

An example of a framework to calculate the section 24J amount to be included in the taxpayer's income tax assessment in terms of the yield to maturity method is provided by Stiglingh, Koekemoer, van Schalkwyk, Wilcocks, de Swart and Jordaan (2014:788). This framework is used in this article to calculate the section 24J accrual amount. The following eight steps need to be performed by the taxpayer in determining the accrual amount:

Step 1: Determine whether section 24J applies

It has already been determined in this article that pre-production raising fees incurred fall within the definition of interest or related finance charges and should therefore be deductible in terms of section 24J. 
Step 2: Calculate the projected cash flow over the period of the instrument

Step 2 entails the calculation of the cash flow over the period of the instrument. It is important to note that for purposes of this article the focus will be whether or not the taxpayer is disadvantaged due to the deletion of section $11(\mathrm{bA})$ and its replacement by section $11 \mathrm{~A}$, specifically in relation to raising fees. The income tax treatment of raising fees and not conventional interest will thus be discussed. To illustrate the differences between these two sections the following assumptions are made in the example:

- a loan of R10 million is received by the taxpayer at the beginning of the year of assessment;

- the loan is to be repaid at the end of a 10 -year period;

- the loan is interest-free to ensure that the study focuses only on raising fees;

- pre-production raising fees of R100000 are incurred during the obtaining of the loan to expand the taxpayer's trade;

- net cash inflow as a result at the beginning of year 1 is R9.9 million, which consists of the R10 million loan reduced by the R100 000 raising fees paid;

- the accrual period of the section 24J interest is the same as the taxpayer's year of assessment; and

- the cash outflow at the repayment of the loan at the end of year 10 is R10 million.

The cash flow in terms of this example is illustrated by TABLE 1 :

\section{TABLE 1: Cash flow schedule}

\begin{tabular}{ccc}
\hline Year & Cash flow & Comments \\
\hline Beginning of year l & R9 900000 & Cash inflow \\
End of year 1 & - & \\
End of year 2 & - & \\
End of year 3 & - & \\
End of year 4 & - & \\
End of year 5 & - & \\
End of year 6 & - & \\
End of year 7 & - & \\
End of year 8 & - & Cash outflow \\
End of year 9 & $($ R10 000 000) & \\
End of year 10 & & \\
\hline
\end{tabular}

Source: Author's analysis

Step 3: Calculate the yield to maturity

The third step in the framework is to calculate the yield to maturity. Section 24J(1) defines this concept as follows:

"yield to maturity -

means the rate of compound interest per accrual period at which the present value of all amounts payable or receivable in terms of any instrument in relation to a holder or an issuer, as the case may be, of such instrument during the term of such 
instrument equals the initial amount in relation to such holder or issuer of such instrument: Provided that where -"

The accrual period in the example is given as 10 years of the loan. It follows that the application of the yield to maturity on the initial amount (or adjusted initial amount) will result in the initial amount (or adjusted initial amount) at the end of the instrument's period being the same as the amount to be repaid. Stiglingh et al. (2014:787) defines the term as the rate which will result in the net present value of zero. The yield to maturity, based on the amounts provided in step 4 , is calculated as $0.100554 \%$.

Compound interest used in the calculation is zero percent due to the fact that the raising fees are a once-off fee and as a result incur no compound interest.

Step 4: Determine the initial amount

The other relevant concepts as defined in the yield to maturity definition read as follows:

"initial amount -

means the issue price or transfer price, as the case may be, in relation to an instrument;"

"adjusted initial amount -

in relation to the holder of an income instrument with regard to a particular accrual period, the sum of the initial amount and the accrual amounts in relation to all previous accrual periods and any other payments made by such holder during all such previous accrual periods less any payments received by such holder during all such previous accrual periods, in terms of such income instrument; or"

The initial amount in the illustration is R9 900000 , which is the net cash outflow at the beginning of year 1 of obtaining the loan.

Step 5: Calculate the accrual amount for the first accrual period. The formula used to calculate the accrual amount can be given as $A=B X C$, where $A$ is the accrual amount, $B$ is the yield to maturity and $C$ is the initial amount:

The accrual amount is calculated in years by multiplying the initial amount by the yield to maturity rate $(\mathrm{R} 9900000 \times 0.100554 \%)$. The accrual amount in year 1 is therefore $\mathrm{R} 9954.83$ (refer to TABLE 2).

Step 6: Calculate the adjusted initial amount. This amount is to be used as "C" in the formula $A=B X C$ :

The adjusted initial amount in year 2 is calculated by adding the initial amount to the accrual amount in year 1. The adjusted initial amount in year 2 is therefore R9 909954.83 (R9 $900000+$ R9 954.84 - refer to TABLE 2).

Step 7: Calculate the accrual amount for the second accrual period:

The accrual amount for the second accrual period is calculated by multiplying the adjusted initial amount by the yield to maturity rate (R9 $909954.84 \times 0.10554)$. The accrual amount in year 2 is therefore R9 964.84 (refer to TABLE 2).

Step 8: Repeat steps 6 to 7 for the remaining accrual periods: 
See TABLE 2 for the example regarding the repeating of steps 6 to 7 as well as the cumulative accrual amount.

TABLE 2: Calculation of the adjusted initial amount as well as the accrual amount for years 1 to 10

\begin{tabular}{|c|c|c|c|c|}
\hline End of year & $\begin{array}{c}\text { Adjusted initial } \\
\text { amount }\end{array}$ & $\begin{array}{l}\text { yield to maturity } \\
\text { rate }\end{array}$ & Accrual amount & $\begin{array}{c}\text { Cumulative } \\
\text { accrual amount }\end{array}$ \\
\hline 1 & R9 900000.00 & $0.100554 \%$ & R9 954.84 & R9 954.84 \\
\hline 2 & R9 909954.84 & $0.100554 \%$ & R9 964.84 & R19919.68 \\
\hline 3 & R9 919919.68 & $0.100554 \%$ & R9 974.86 & R29 894.54 \\
\hline 4 & R9 929894.54 & $0.100554 \%$ & R9 984.89 & R39 879.43 \\
\hline 5 & R9 939879.43 & $0.100554 \%$ & R9 994.93 & R49 874.36 \\
\hline 6 & R9 949874.36 & $0.100554 \%$ & R10 004.98 & R59 879.34 \\
\hline 7 & R9 959879.34 & $0.100554 \%$ & R10 015.05 & R69 894.39 \\
\hline 8 & R9 969894.39 & $0.100554 \%$ & $\mathrm{R} 10025.12$ & R79 919.51 \\
\hline 9 & R9979919.51 & $0.100554 \%$ & R10 035.20 & R89 954.71 \\
\hline \multirow[t]{2}{*}{10} & R9989954.71 & $0.100554 \%$ & R10 045.29 & R100000.00 \\
\hline & & & $\mathrm{R} 100000.00$ & \\
\hline
\end{tabular}

Source: Author's analysis

To determine whether or not the taxpayer is in a disadvantaged position due to the deletion of section $1 \mathrm{l}(\mathrm{bA})$ and its replacement by section $11 \mathrm{~A}$ (together with section 24J) four scenarios will be created. The income tax deductions based on sections $11(\mathrm{bA}), 11 \mathrm{~A}$ and $24 \mathrm{~J}$ will be calculated based on these scenarios. These income tax deductions will be based on the assumptions as provided in this article. The accrual amount calculated in terms of section 24J will be based on the calculation in steps 1 to 8 above. The present value of the different scenarios will be calculated and will be compared to each other to answer the primary question raised in this article. In all scenarios section $11 \mathrm{~A}$ and $24 \mathrm{~J}$ will be discussed firstly followed by section 11 (bA) with a summary and conclusion at the end of the scenarios.

\section{Scenario 1}

In the first scenario the commencement date of the taxpayer's trade is at the end of year 3 of the repayment term of the loan. The asset purchased in terms of the loan will however be brought into use only in year 8 of the repayment term of the loan.

The accrual amount of the incurred raising fees in terms of section 24J is different from year to year (refer to TABLE 2). The yearly accrual amount will be calculated in terms of section 24J(2) for the period in which the trade has not yet commenced.

The accrual amounts calculated from the start of the repayment period of the loan till the date of commencement of trade will be added together and allowed as a once-off deduction when the trade commences in terms of section 11A. The full cumulative raising fee accrual amount of R29 984.54 (calculated as the sum of the accrual amounts for the first three years as indicated in TABLE 2) is therefore deductible in terms of section $11 \mathrm{~A}$ at the end of year 3 . The date at which the asset is brought into use is held to be not relevant in terms of this section, as the section states only that it should be determined when the trade commences. 
The accrual amounts for the remaining raising fees will be calculated in the following years in terms of section $24 \mathrm{~J}(2)$. The present value of the raising fees in terms of sections $11 \mathrm{~A}$ and $24 \mathrm{~J}$ in the scenario is R74 303.70 (refer to TABLE 3 at the end of the scenarios). The present value is calculated by the imputation of the following in the HPIOb/l Financial Calculator (the method to be repeated for the calculation of the section 11A, 24J deduction in the other scenarios and will not be indicated again) based on the accrual amounts as calculated in TABLE 2.

\begin{tabular}{|c|c|c|c|c|c|}
\hline $\begin{array}{c}\text { Function } \\
\text { key }\end{array}$ & Amount key & Comments & $\begin{array}{c}\text { Function } \\
\text { key }\end{array}$ & Amount key & Comments \\
\hline $\mathrm{P} / \mathrm{YR}$ & 1 & & CFj & $\mathrm{R} 10004.98$ & \\
\hline CFj & R0.00 & & $\mathrm{CFj}_{\mathrm{i}}$ & $\mathrm{R} 10015.05$ & \\
\hline $\mathrm{CFj}$ & R0.00 & & $C F j$ & $\mathrm{R} 10025.12$ & \\
\hline $\mathrm{CFj}$ & Ro.00 & & CFj, & $\mathrm{R} 10035.20$ & \\
\hline $\mathrm{CFj}$ & R29 894.54 & Section IlA deduction & $\mathrm{CFj}_{\text {. }}$ & $\mathrm{R} 10045.29$ & \\
\hline $\mathrm{CFj}$ & R9 984.89 & $\begin{array}{l}\mathrm{CFj}-\mathrm{CFj} \text { are section 24J } \\
\text { deductions }\end{array}$ & I/YR & $5.4 \%$ & Discount rate \\
\hline $\mathrm{CFj}_{\text {. }}$ & R9 994.93 & & NPV & R74 303.70 & $\begin{array}{l}\text { Net present value of } \\
\text { sections } 11 \mathrm{~A} \text { and } 24 \mathrm{~J} \\
\text { deductions }\end{array}$ \\
\hline
\end{tabular}

The income tax treatment or pre-production raising fees incurred if section $11(\mathrm{bA})$ was still in affect allowed for the full deduction of the raising fee incurred only at the end of year 8 . This is despite the fact that the trade commenced in year 3 . The present value of the section $11(\mathrm{bA})$ deduction in this scenario is R65 656.10 (refer to TABLE 3).

\section{Scenario 2}

For scenario 2 the same information as per scenario 1 will be used with the only exception being that the asset will be brought into use in year 3 in a trade. For sections 11A and 24J there will be no change in the present value of the deduction. For these two sections the date when a trade commences is important to distinguish between when the deduction is governed by section $11 \mathrm{~A}$ and by section 24J. In this scenario the date on which the asset is brought into use is the only change and not the commencement date of the trade. As such the present value of the deductions is R74 303.70 (refer to TABLE 3).

The income tax treatment in terms of section $11(\mathrm{bA})$ also follows scenario 1 in which the deduction is granted in full in the year of assessment in which the asset is brought into use, given that a trade has already commenced by then. The full R100 000 will therefore be allowed as a deduction in year 3 , which will result in the present value of the raising fee deduction in terms of section 11 (bA) in this given scenario being R85 403.99 (refer to TABLE 3).

\section{Scenario 3}

In scenario 3 the date of the commencement of trade changes from the end of year 3 to the end of year 5 of the repayment period of the loan. The asset purchased with the loan obtained will also be brought into use at the end of year 5 , when the trade commences.

The income tax treatment of raising fees in terms of section $11 \mathrm{~A}$ and section 24J changes in scenario 3 due to the commencement of trade only starting at the end of year 5 and not in year 3. The cumulative accrual amounts at the end of year 5 will therefore be allowed as a deduction in year 5. The cumulative accrual amount, as per TABLE 2, for the first five years is R49 874.36. 
The accrual amount of the remaining periods raising fees will be determined based on section $24 \mathrm{~J}(2)$ and allowed in each year as a deduction. The present value of all the deductions of raising fees in terms of section $11 \mathrm{~A}$ and section 24) in this scenario is R71 340.12 (refer to TABLE 3).

The income tax deduction in terms of section $11(\mathrm{bA})$ would have been the full deduction in year 5 , when a trade has already commenced and the asset brought into use. The present value of the section 11 (bA) deductions in terms of this scenario is R76 877.09 (refer to TABLE 3).

\section{Scenario 4}

In scenario 4 the trade commenced at the end of year 7 of the repayment period of the loan. The asset purchased through the loan obtained will be brought into use at the end of year 8 of obtaining the loan.

The last scenario to be discussed is where the commencement of a trade starts at the end of year 7. The accrual amounts calculated for the first seven years will be allowed as a lump-sum deduction at the end of year 7 . The total accrual amounts therefore allowable as a deduction in terms of section IlA at the end of year 7 come to R69 894.39 (refer to TABLE 3). The remaining raising fees accrual amounts as calculated in terms of section 24J(2) will be deducted at the end of each remaining year. The present value of the raising fee deductions in terms of section $11 \mathrm{~A}$ and section 24J in the scenario is R67 138.11 (refer to TABLE 3).

The income tax treatment in terms of section $11(\mathrm{bA})$ indicates that the deduction can only be taken in full at the end of year 8 , when both the trade has commenced and the asset brought into use for that trade. The present value of the deductions in terms of section $11(\mathrm{bA})$ in this scenario is R65 656.10 (refer to TABLE 3).

\section{TABLE 3: Illustration of the income tax treatment of scenarios 1 to 4}

\begin{tabular}{|c|c|c|c|c|c|c|c|c|}
\hline \multirow[b]{2}{*}{ year } & \multicolumn{2}{|c|}{ Scenario 1} & \multicolumn{2}{|c|}{ Scenario 2} & \multicolumn{2}{|c|}{ Scenario 3} & \multicolumn{2}{|c|}{ Scenario 4} \\
\hline & $\begin{array}{c}\text { Section } \\
\text { IIA/24J } \\
\text { deduction }\end{array}$ & $\begin{array}{c}\text { Section } \\
11(b A) \\
\text { deduction }\end{array}$ & $\begin{array}{c}\text { Section } \\
\text { 11A/24J } \\
\text { deduction }\end{array}$ & $\begin{array}{c}\text { Section } \\
11(b A) \\
\text { deduction }\end{array}$ & $\begin{array}{c}\text { Section } \\
11 \mathrm{~A} / 24 \mathrm{~J} \\
\text { deduction }\end{array}$ & $\begin{array}{c}\text { Section } \\
11(b A) \\
\text { deduction }\end{array}$ & $\begin{array}{c}\text { Section } \\
\text { 11A/24J } \\
\text { deduction }\end{array}$ & $\begin{array}{c}\text { Section } \\
11(b A) \\
\text { deduction }\end{array}$ \\
\hline 1 & - & - & - & - & - & - & - & - \\
\hline 2 & - & - & - & - & - & - & - & - \\
\hline 3 & R29 894.54 & - & R29 894.54 & $\mathrm{R} 100000.00$ & - & - & - & - \\
\hline 4 & R9 984.89 & - & R9 984.89 & - & - & - & - & - \\
\hline 5 & R9 994.93 & - & R9 994.93 & - & R49 874.36 & R100000.00 & - & - \\
\hline 6 & R10 004.98 & - & $\mathrm{R} 10004.98$ & - & $\mathrm{R} 10004.98$ & - & - & - \\
\hline 7 & R10 015.05 & - & R10 015.05 & - & R10 015.05 & - & R69 894.39 & - \\
\hline 8 & R10 025.12 & $R 100000.00$ & $\mathrm{R} 10025.12$ & - & $\mathrm{R} 10025.12$ & - & $\mathrm{R} 10025.12$ & $\mathrm{R} 100000.00$ \\
\hline 9 & R10 035.20 & - & R10 035.20 & - & R10 035.20 & - & R10 035.20 & - \\
\hline 10 & R10 045.29 & - & R10 045.29 & - & $\mathrm{R} 10045.29$ & - & R10 045.29 & - \\
\hline $\begin{array}{l}\text { Discount } \\
\text { rate }(\mathrm{CPI}) \text { * }\end{array}$ & $5.4 \%$ & $5.4 \%$ & $5.4 \%$ & $5.4 \%$ & $5.4 \%$ & $5.4 \%$ & $5.4 \%$ & $5.4 \%$ \\
\hline $\begin{array}{l}\text { Present } \\
\text { value }\end{array}$ & R74 303.70 & R65 656.10 & R74 303.70 & R85 403.99 & R71 340.12 & R76 877.09 & R67 138.11 & $R 65656.10$ \\
\hline
\end{tabular}

Source: Author's analysis

*Consumer Price Index December 2013 - Statistics South Africa 


\section{Summary of scenarios 1 to 4}

There is significant difference in the present value of the deductions in scenario 1 , where the trade commenced at the end of year 3 but the asset was brought into use in that trade only at the end of year 8 . The present value of the section IIA and section 24J deductions exceeds that of the present value of the section $11(\mathrm{bA})$ deduction. It can be submitted that the new legislation is more beneficial to taxpayers in scenarios where there is a significant time delay between when the trade commenced and the asset being brought into use after the commencement of the trade.

In scenario 2 the commencement of trade date agrees with the date as per scenario 1 . The asset, however, is now brought into use at the end of year 3 . The present value of the section $11(\mathrm{bA})$ deductions in this scenario is greater than the present value of the deduction as per section $11 \mathrm{~A}$ and section 24J. It can be submitted that section $11(\mathrm{bA})$ is more beneficial than section $11 \mathrm{~A}$ and section 24J in instances where the asset is brought into use shortly after the trade commenced. The benefit in terms of section $11(b A)$, however, reduces the more time has gone by since the payment of the raising fees and the asset being brought into use in the trade of the taxpayer. This can be deducted from the decrease in the difference of the present values of section $11 \mathrm{~A}$ and section $1 \mathrm{l}(\mathrm{bA})$ in scenario 2 to 4 . A point will be reached, as is the case in scenario 4 , due to the time delay since the incurring of the raising fee and the commencement of the trade that the section $11 \mathrm{~A}$ and section $24 \mathrm{~J}$ deduction will be more beneficial than the section $1 \mathrm{l}(\mathrm{bA})$ deduction (refer to TABLE 3).

\section{SUMMARY AND CONCLUSION}

It is argued that the meaning assigned to interest or related finance charges in terms of section $11(b A)$ should also be assigned to the words in terms of section 24J. Raising fees should therefore be included in the defined meaning of interest or related finance charges as per section 24J. Raising fees are also deductible in terms of section $11 \mathrm{~A}$ when the carrying on trade commences due to the fact that these items are deductible in terms of section 24J.

It is submitted that the meaning assigned to interest and related finance costs given in terms of section $1 \mathrm{l}(\mathrm{bA})$ should be given to the same words in terms of section 24J. Raising fees should therefore be read with interest and related finance costs as defined by section 24J. Raising fees are also deductible in terms of section $11 \mathrm{~A}$ when the carrying on trade commences due to the fact that it is deductible in terms of section 24J. Any remaining portion of the raising fee, if applicable, which was not deducted in terms of section 11A will after the commencement of the carrying out of a trade be deducted under section 24J and spread over the remaining period of the instrument.

The income tax treatment of raising fees falling within the definition of interest or related finance charges is determined on the basis of whether the trade in terms of which they are incurred has already commenced. It is submitted that pre-production raising fees incurred create a new trade and that when the trade commenced, these costs were to be deducted under section $11 \mathrm{~A}$. For all periods after the trade has commenced, the deduction should be determined in terms of section 24J.

The income tax treatment of pre-production raising fees incurred to expand an existing trade is currently determined on the basis of section 11 A or section 24J. In both instances the annual deduction will be calculated in terms of the working of section 24J, with the significant 
difference being that the section 11A deduction will be deductible only in the year in which the carrying on of a trade commences. The section 24J deduction will be spread over the term of the instrument.

The recently deleted section $11(\mathrm{bA})$ determined that the deduction of pre-production raising fees incurred during the expansion of an existing trade will be allowable as soon as the asset is brought into use in the carrying on of a trade. In contrast to section $11(\mathrm{bA})$, section $11 \mathrm{~A}$ allows for the accrued annual interest over the term of the instrument, as provided by section 24J, as a deduction when the carrying on of trade commences. Due to the replacement of section 11 (bA) by section IlA there is a change in the timing of the deduction, from when the asset is brought into use during the carrying on of trade to only when the carrying on of a trade has commenced.

Section 11A(2) does not allow for the deduction to create or enlarge an assessed loss for the taxpayer, and the deductions may also not be used against the taxable income of the taxpayer from existing trades. The section $11(\mathrm{bA})$ deduction, however, allows for an assessed loss to be created or enlarged. Section $11(b A)$ is therefore more beneficial in the starting-up phase of a trade than section IIA if there is not any taxable income to utilise the raising fees incurred against.

It is therefore submitted that the new legislation (section $11 \mathrm{~A}$ with section 24J) is in certain instances more disadvantageous to the taxpayer when compared to section $11(b A)$. This scenario occurs when the trade commenced almost immediately after the pre-production raising fees are incurred and the asset is brought into use only after a significant period of time has elapsed. The tax benefit of section 11 (bA) over section 11 A (read with section 24J) gradually becomes smaller and smaller as the difference in time between the incurring of the raising fees and the asset being brought into use in the taxpayer's trade becomes greater. A point is reached, however, where there is no longer a tax benefit in terms of section $11(b A)$ and that, as in the first scenario, the section $11 \mathrm{~A}$ and $24 \mathrm{~J}$ deduction is more beneficial to the taxpayer.

\section{LIST OF REFERENCES}

Black's Law Dictionary. (2007). 2nd Edition. St Paul, Minnesota: West Publishing Co.

Brincker, T.E. (201la). Taxation Principles of Interest and Other Financing Transactions. Electronic Version. Updated May 2011. LexisNexis. Available: http://za-zatlxn001:8090/ nxt/gateway.dll?f=templates $\$ f n=$ default.htm $\$$ vid =mylnb:10.1048/enu [2013, April 10]

Brincker, T.E. (2011b). The deduction of funding costs. Available: http://www. Money webtax.co.za/moneywebtax/view/moneywebtax/en/page197?oid=64008\&sn=Detail [2013, April 6].

CIR v Genn \& Co (Pty) Ltd 1955 (3) SA 293 (A), 20 SATC 113.

C:SARS v South African Custodia/ Services (Pty) Ltd 2012 (1) SA 522 (SCA), 74 SATC 61.

Clegg, D. (2012). In the beginning. Tax Planning Corporate and Personal, 26(3), pp. 71-72.

Correia, C., Flynn, D., Uliana, E., \& Wormald, M. (2013). Financial Management, 7th edition. Cape Town: Juta and Company Ltd.

De Jager, T. (1987). The deductibility of raising fees. SA Tax Journal, 2(1), pp. 1-11. 
De Koker, A.P., \& Williams, R.C. (2014). Silke on South African Income Tax. Electronic version. Updated May 2014. LexisNexis. [Online] Available: http://www.mylexisnexis.co.za.ez.sun.ac.za /nxt/gateway.dll?f=templates\$fn=default.hht\$vid=mylnb:10.1048/enu [2013, April 9].

De Villiers, D.B.M. (2001). Die inkomstebelastinggevolge van die verkryging van 'n skuldbrief teen 'n diskonto. Unpublished M.Acc. (Taxation) dissertation. Stellenbosch: University of Stellenbosch.

Emslie, C. (2010). The tax deductibility of interest on money borrowed to pay penalties imposed by the Competition Tribunal in terms of the Competition Act, 89 of 1998. Unpublished Masters in Tax dissertation. Cape Town: University of Cape Town.

Income Tax Act No.58 van 1962 (as amended).

ITC 882 (1959) 23 SATC 239 (T).

ITC 995 (1962) 25 SATC 137 (T).

ITC $1019(1962) 25$ SATC $411(\mathrm{~N})$.

Kellaway, E.A. (1995). Principles of Legal Interpretation: statutes, contracts and wills. Durban: Butterworths.

Minister of the Interior v Machadodorp Investments (Pty) Ltd 1957 (2) SA 395 (A), 2 All SA 355 (A).

Robin Consolidated Industries Limited v CIR 1997 (3) SA 654 (SCA), 2 All SA 195 (A).

South African Revenue Service. (1995). Explanatory Memorandum on Income Tax Bill. Pretoria: SARS, Legal and Policy Division.

South African Revenue Services. (2009). Interpretation Note 51: Pre-trade expenditure and losses. Pretoria: SARS, Legal and Policy Division.

South African Revenue Service. (2004). Explanatory Memorandum on the Revenue Laws Amendment Bill. Pretoria: SARS, Legal and Policy Division.

Statistics South Africa. (2013). Consumer Price Index December 2013. [Online]. Available: http://beta2.statssa.gov.za/publications/P0141/P0141December2013.pdf [2014, March 5].

Stiglingh, M., Koekemoer, A.D., van Schalkwyk, L., Wilcocks, J.S., de Swardt, R.D., \& Jordaan, K. (2011). Silke: Suid-Afrikaanse Inkomstebelasting 2011. Durban: LexisNexis.

Stiglingh, M., Koekemoer, A.D., van Schalkwyk, L., Wilcocks, J.S., de Swardt, R.D., \& Jordaan, K. (2014). Silke: Suid-Afrikaanse Inkomstebelasting 2014. Durban: LexisNexis.

Stretch, R., \& Silke, J. (2000). Deductibility of Raising Fees in terms of s 1 l (bA) of the Income Tax Act. Taxgram (July 2000).

Williams, R.C. (1997). Can Expenditure on Interest be of a Capital Nature? The South African Law Journal, 114(Part IV), pp. 641-644.

Witthoft, V. (2011). Pre-trade interest incurred on land purchased. Tax Planning Corporate and Personal, 25(6).

Zulman, R.H., Stretch, R., \& Silke, J. (2013). Deductions - Raising fees - Section 11 (bA) and Section 11 (bB) Income Tax Practice Manual. Electronic version. Updated December 2013. LexisNexis. [Online] Available: http://www.mylexisnexis.co.za.ez.sun.ac.za/nxt/gateway.

dll?f=templates $\$$ fn $=$ default.htm $\$$ vid $=$ mylnb:10.1048/enu [2013, April 8]. 